\title{
SIDERURGICAL TECHNIQUE IN JAPAN 1953
}

\author{
Hiroshi Sawamura \\ Dr. Eng. President of The Iron \& Steel Institute of Japan
}

To overcome unfavorable iron-making conditions as compared with those of occidental countries, the iron and steel industry in Japan started some years ago a rationalization in the equipment, technique and methods of management. Majority of rationalization in the blast furnaces and open hearth furnaces had been completed by the end of 1952 . On the other hand the rationalization of steel rolling had been delayed behind the aforementioned workings. The important workings of the equipments concerned had been much in progress and greater part of them would have been completed in 1954 .

Three companies such as Kawasaki Seitetsu Kabushiki Kaisha (Kawasaki Iron Mfg. Co., Ltd.), K. K. Nakayama Seikojo (Nakayama Steel Co., Ltd.) and Amagasaki Seitetsu K. K. (Amagasaki Iron Mfg. Co., Ltd.) began to start the blast furnace operation in 1953. A blast furnace with 500-ton capacity was newly established in Chiba Iron Works of Kawasaki Seitetsu K.K. They applied thereto both methods of pelletizing and ore-bedding which had not been utilized heretofore in Japan. K. K. Nakayama Seikojo holds 2 units of 450-ton blast furnaces in Osaka, while Amagasaki Seitetsu K. K. was equipped with one 450-ton blast furnace in Amagasaki. In the aforementioned two firms each one blast furnace had been rearranged and was blown in anew. In Amagasaki Seitestujo, used sinter of the pyrite cinder as the main material that had been decuperized by a simple wet process before sintering. This decuperation were performed in recent years also in Hirohata Iron Works of Fuji Seitetsu K. K. (Fuji Iron \& Steel Co., Ltd.) and displayed a special significance in iron industry in Japan.

Much noticeable change had not been observed in the equipment of open hearth furnaces in Japan excepting renovation or new installation of a few open hearth furnaces and new installation of the oxygen-generating equipment.

The study of ingot cases was very active in Japan. K. K. Kobe Chutetsujo (Kobe Iron Foundry Co., Ltd.) and Kubota Tekko K. K. (Kubota Iron Works Co., Ltd.) made success in manufacturing about 2.4-ton ingot moulds of ductile cast iron for the piping material with good results. There were no such comparable example in Japan and overseas and it was a remarkable improvement in the ingot-making.

Main examples of rolling equipments completed in 1953 were improvement of the high-grade electrical sheet plant in Yawata Iron Works, new installation of the medium plate plant in Hirohata Iron Works, new establishment of a blooming mill in Kawasaki Iron Works of Nippon Kokan K. K. (Nippon Steel Tube Co., Ltd.) and additional installation of a reversible four-high cold rolling mill in Kudamatsu Plant of Toyo Kohan K. K. (Oriental Steel Sheet Co., Ltd.) 
It must be especially mentioned that various equipments of instrumentation had been set in order in iron and steel plants in Japan and the role of instrumentation was very great for promotion of iron and steel industry in Japan.

With progress of rationalization of iron and steel industry in Japan, the effect of the rationalization on the siderurgical economy in Japan was much pronounced. As for the fuel economy, the average coke ratio of blast furnaces in Japan which was 0.92 in January 1952 and 0.85 in January 1953, was reduced to 0.79 in January 1954. On the other hand, the average analysed unit of fuel consumption of open furnaces in Japan was sharply reduced to $1.80 \times 10^{6} \mathrm{kcal}, 1.52 \times 10^{6} \mathrm{kcal}$ and $1.27 \times 10^{6}$. These figures showed a tendency more and more decreasing in future.

The siderurgical production in Japan 1953 proved 4,520,000 tons pig iron, 7,760,000 tons steel ingots and 5,180,000 tons hot-rolled products. As shown in Table 1, it was a maximum in some years since the defeat. This was nothing but the result of a great progress in rationalization of iron and steel industry in Japan as well as the result of stimulation by such a boom in domestic demand that the apparent domestic consumption of iron and steel (including the amount of indirect exportation) attained to about 4,500,000 tons.

Table 1. Production of Iron and Steel in Japan (1,000 ton)

\begin{tabular}{cccc}
\hline Year & Pig iron & Steel ingot & Hot rolled products \\
\hline 1946 & 218 & 684 & 326 \\
1947 & 397 & 1,102 & 578 \\
1948 & 1,000 & 2,087 & 1,231 \\
1949 & 1,687 & 3,475 & 2,263 \\
1950 & 2,433 & 5,300 & 3,580 \\
1951 & 3,137 & 6,502 & 4,563 \\
1952 & 3,474 & 6,988 & 4,638 \\
1953 & 4,518 & 7,662 & 5,182 \\
\hline
\end{tabular}

In conclusion some remarks must be mentioned about cooperative studies of science and engineering of 1ron and steel now currently performed in Japan. Typical research groups were as follows:

1) Research groups helped by debentures of the scientific research expense of Education Ministry: Scientific studies on siderurgy were performed mainly by university professors.

2) Tekko-Gijutsu-Kyodo-Kenkyukai (Siderurgical Technique Cooperative Research Association) consisting of Heavy Industries Bureau of MITI (Ministry of International Trade and Industry), Nippon Tekko Kyokai (The Iron \& Steel Institute of Japan) and Nippon Tekko Remmei (Japan Iron \& Steel Federation): Studies on siderurgical techniques were made by engineers of main iron and steel firms and university professors.

3) The 19th and 54th Committees of Nippon Gakujutsu Shinkokai (Japan Society for Promotion of Sciences): Both Committees were organized by engineers of typical iron and steel firms and university professors. Important scientific and technical problems relating to improvement in the quality of steel were studied by the former Committee, while central scientific and technical problems predominantly on the pig iron-making were studied by the latter Committee.

In observation of siderurgical technique in Japan, the effect of presence of such synthetic research institutions on the progress and development of siderurgy should not be neglected. 